\title{
Preparation of Novel Al-Er Master Alloys in Chloride-Fluoride Melt
}

\author{
Kosov Yaroslav Igorevich ${ }^{1, a^{*}}$, Bazhin Vladimir Yuryevich ${ }^{1, b}$ \\ ${ }^{1}$ Saint-Petersburg Mining University, Saint-Petersburg, Russia \\ ayaroslav_kosov@spmi.ru, bbazhin-alfoil@mail.ru
}

Keywords: aluminium, master alloys, erbium, Al-Er, metallothermic reduction, chloride-fluoride melt, $\mathrm{NaErF}_{4}$, microstructure, intermetallic compound, $\mathrm{Al}_{3} \mathrm{Er}$.

\begin{abstract}
A novel Al-Er master alloy has been prepared through situ metallothermic reactions of $\mathrm{NaErF}_{4}$ and aluminium melts. The compound $\mathrm{NaErF}_{4}$ is formed as a result of the interaction of $\mathrm{NaF}$ and $\mathrm{ErF}_{3}$ in the melt medium $\mathrm{KCl}$. The metallothermic reactions produce erbium, which through low solubility in molten aluminium and forms intermetallic compound $\mathrm{Al}_{3} \mathrm{Er}$. The microstructures of the Al-Er master alloy with different contents of the alloying metal has been investigated. The results showed that the Al-Er master alloy mainly consisted of phases of $\alpha-\mathrm{Al}$ and $\mathrm{Al}_{3} \mathrm{Er}$, that confirmed by the results of X-ray diffraction. Backscattered electron imaging of the Al-Er master alloy under a scanning electron microscope (SEM) revealed the presence of phase $\mathrm{Al}_{3} \mathrm{Er}$, which crystallized in the eutectic composition $\left[\mathrm{Al}+\mathrm{Al}_{3} \mathrm{Er}\right]$. The observed microstructure is explained according to the eutectic reaction in an Al-Er phase diagram. The preparation of Al-Er master alloy by the metallothermic reduction method will allow to reduce energy consumption for master alloy production and to reduce the cost of aluminium alloys alloyed with Er through the novel master alloy.
\end{abstract}

\section{Introduction}

To improve mechanical properties and workability of aluminum alloys, it is now an effective method to add of trace amount of rare earth metals (REM) to aluminum melt. In the recent years of research studies the effect of low additions of erbium on the properties and microstructure of aluminum and its alloys has been intense [1-10]. The typical content of erbium in wrought and aluminium cast alloys are varies from 0.01 to 1.0 mass $\%$, but preferably $0.1-0.3$ mass $\%$ [11].

Erbium form thermodynamically stable $\mathrm{L}_{2}$-ordered $\mathrm{Al}_{3} \mathrm{Er}$ precipitates during ageing heat treatment [12]. These precipitates can improve the creep resistance in coarse-grained Al-based alloys [13]. Erbium is potentially an efficient grain refiner for wrought and aluminum cast alloys [1, $3,6,8]$. However, melting point and atomic weight of erbium are $1802 \mathrm{~K}\left(1529^{\circ} \mathrm{C}\right)$, and $167.259 \mathrm{amu}$, respectively, much higher and larger than those of aluminum. Furthermore, the solubility of erbium in aluminum is extremely low. Therefore, it is necessary to prepare Al-Er master alloys for use in aluminum alloy production.

A master alloys is an intermediate alloy containing a sufficient content of the metal added to the melt for obtaining the required chemical composition, structural and technological properties of castings and ingots. Currently, Al-Er master alloys are prepared by direct alloying aluminium with erbium, respectively $[6,8,9,12]$. In its pure form, Er has a high melting point, which leads to losses of the alloying element and the base during melting and significant contaminate of master alloys by non-metallic impurities. As indicated earlier, the use of pure Er is inefficient due to the long and incomplete assimilation of aluminium melts.

Research into the preparation of Al-Er master alloys is still very limited. Al-Er master alloys can be prepared by addition of mixture of salts, which reacts in-situ to produce erbium metal. It is known investigations into the preparation of aluminium master alloys with scandium [14-16], zirconium [17], yttrium [18] and multicomponent [18, 19] by metallothermic reduction of molten salts.

The aim of the present work was to study the preparation Al-Er master alloys by metallothermic reduction of chloride-fluoride melt, investigation of the microstructure and phase composition of master alloys with different content of erbium and find out optimum content of erbium in novel master alloys for foundry industry. 


\section{Experimental Procedure}

In this study, erbium fluoride $\left(\mathrm{ErF}_{3}\right)$, sodium fluoride $(\mathrm{NaF})$ and potassium chloride $(\mathrm{KCl})$ were used as the raw materials to acquisition of chloride-fluoride melt (flux). Master alloys were prepared from pellets (round ingots) of Al (A99.9) diameter 5-10 mm and chloride-fluoride melt by an metallothermic reduction process. Reduction melting was carried out in graphite crucibles placed in a resistance furnace. In the laboratory scale melts were made by heating approximately $200 \mathrm{~g}$ of sample at $800^{\circ} \mathrm{C}$ in the furnace. The Al pellets and flux were added to the graphite crucibles then placed in the furnace.

The powder X-ray diffraction (XRD-6000, «Shimadzu») measurement using $\mathrm{Cu} \mathrm{K}_{\mathrm{a}}$ radiation was carried out to identify the crystalline phase of the chloride-fluoride melt.

The microstructure characteristics of Al-Er master alloys were investigated by X-ray diffraction (XRD) and scanning electron microscope (Vega 3 LM, «Tescan»).

\section{Results and Discussion}

The preparation of Al-Er master alloy was studied by aluminothermic reduction of chloridefluoride melts and shown on the following chemical reaction which is supposed to follow via reaction (1):

$$
3 \mathrm{NaErF}_{4}+12 \mathrm{Al}=3 \mathrm{Al}_{3} \mathrm{Er}+\mathrm{Na}_{3} \mathrm{AlF}_{6}+2 \mathrm{AlF}_{3}
$$

were $\mathrm{Al}$ acted as both a reductant as well as base of the master alloy. Mixture of the salts $\mathrm{ErF}_{3}$ and $\mathrm{NaF}$ participate on the formation of the complex compound $\mathrm{NaErF}_{4}$ in the presence of $\mathrm{KCl}$ melt. Erbium content in obtained master alloy depended on the amount of erbium fluoride in original melt.

Mixtures of $\mathrm{ErF}_{3}, \mathrm{NaF}, \mathrm{KCl}$ melt in a ternary eutectic relationship. $\mathrm{NaErF}_{4}$ formation was confirmed by X-ray diffraction (XRD) analysis of the sample of flux (Fig. 1). The observed peaks were identified as $\mathrm{NaErF}_{4}$ and $\mathrm{KCl}$ medium (substrate).

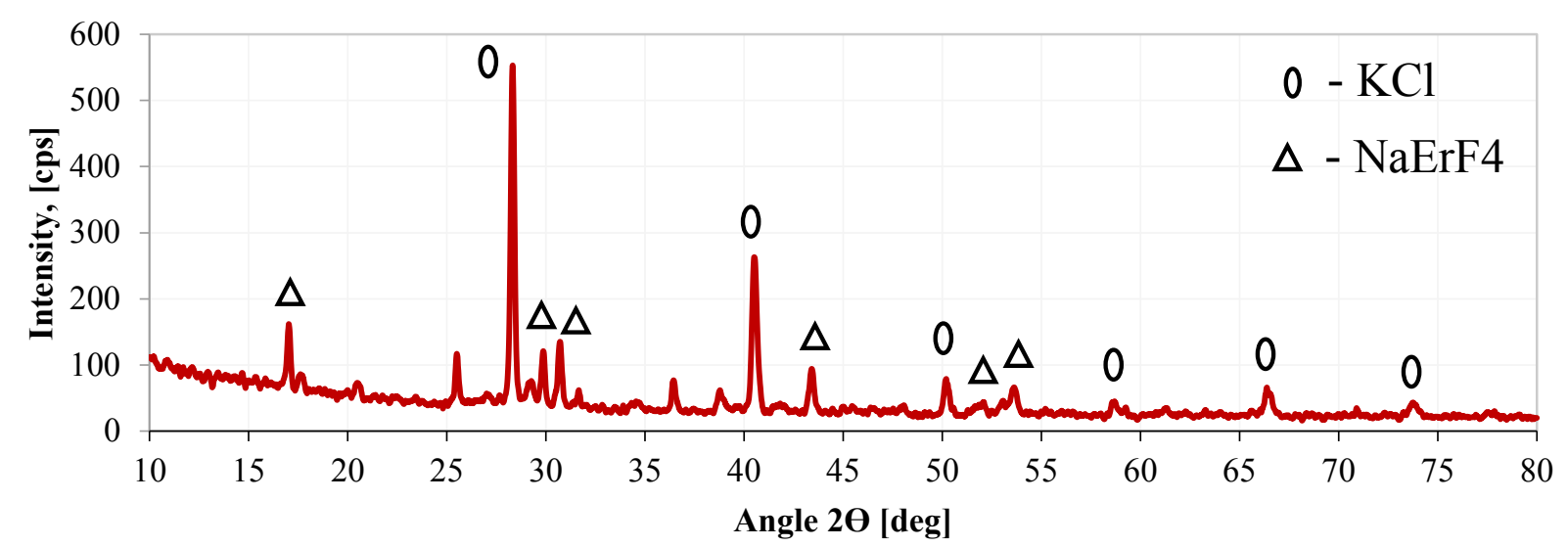

Fig. 1. XRD analysis of the chloride-fluoride melt for preparation Al-Er master alloys.

The general information of the phase diagram Al-Er system the reported in [20]. By the data of the analysis of equilibrium phase diagrams [21] of binary systems, the microstructure of the Al-Er master alloys should contain primary crystals of an aluminum solid solution (Al) and an $\left[(\mathrm{Al})+\mathrm{Al}_{3} \mathrm{Er}\right]$ eutectic. Analysis of the microstructures of the master alloys under a scanning electron microscope (SEM) (Fig. 2) confirms the data of the phase diagrams. It can be seen from Fig. 2 that the microstructure of Al-3.4\% Er master alloy contains primary crystals of (Al) and a dispersed eutectic mixture. Erbium actively react with aluminium and forming intermetallic compounds in the eutectic and in highly disperse form.

The SEM images of samples of Al-Er master alloys with mass \% of Er 4.2 and 6.1 prepared by metallothermic reduction of chloride-fluoride melt are shown in Fig. 3 and Fig. 4 respectively. 


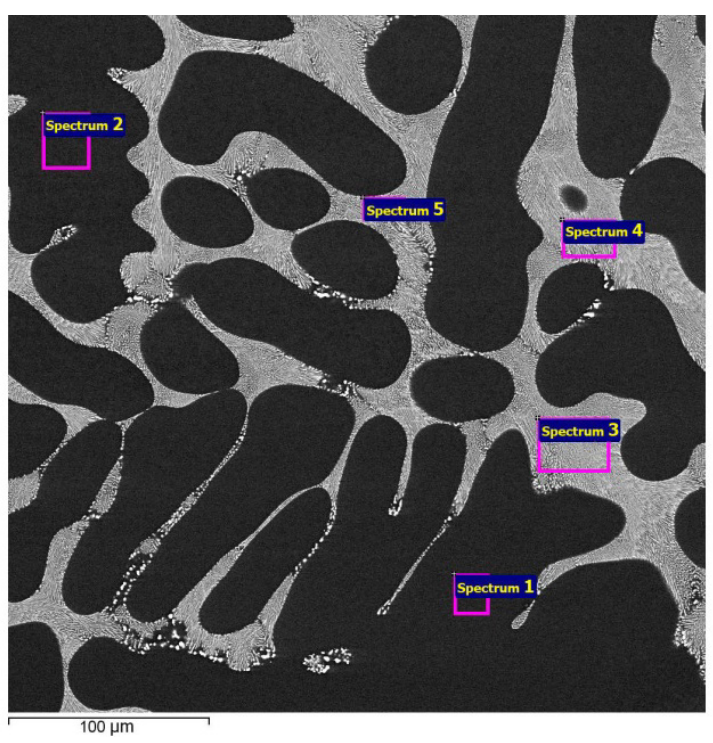

a)

\begin{tabular}{l|cc}
\hline Spectrum & Al [mass \% ] & Er [mass \%] \\
Spectrum 1 & 99.69 & 0.31 \\
Spectrum 2 & 99.58 & 0.42 \\
Spectrum 3 & 87.23 & 12.77 \\
Spectrum 4 & 87.51 & 12.49 \\
Spectrum 5 & 87.83 & 12.17 \\
\hline
\end{tabular}

c)

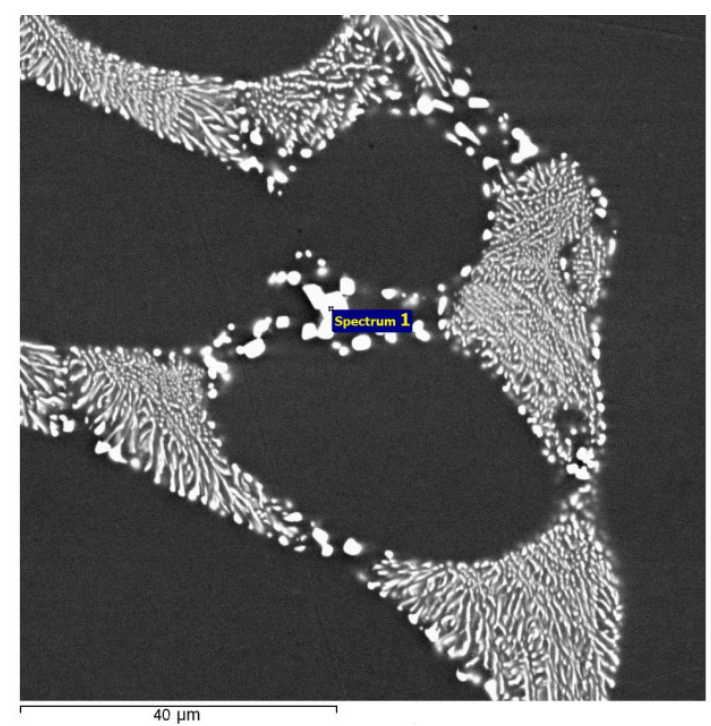

b)

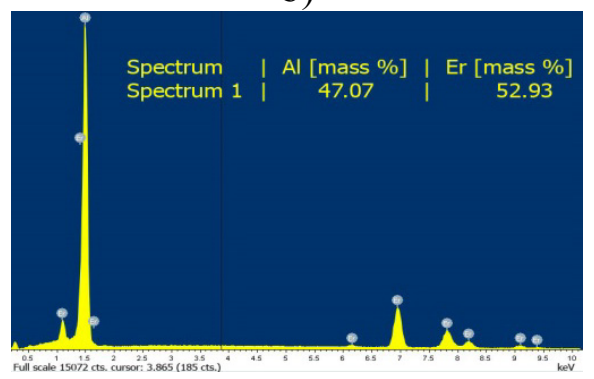

d)

Fig. 2. Microstructure and results of energy dispersive spectrum (EDS) analysis of Al-Er master alloys with 3.4 mass \% Er: a) SEM image; b) SEM image; c) results of EDS analysis of (a); d) spectrum of EDS analysis of (b).

Fig 2-4 indicate that increasing erbium level results in coarsening intermetallic compounds $\mathrm{Al}_{3} \mathrm{Er}$ in eutectic composition. The summarized data about size of the dendrite cells of (Al) and erbium content in the eutectic of master alloys are shown in Table 1.

Table 1. The size of the dendrite cells and erbium content in the eutectic.

\begin{tabular}{|c|c|c|}
\hline $\begin{array}{c}\text { Master alloys, } \\
{[\text { mass \%] }}\end{array}$ & $\begin{array}{c}\text { Size of the dendrite } \\
\text { cells of }(\mathrm{Al})[\mu \mathrm{m}]\end{array}$ & $\begin{array}{c}\text { Erbium content in the } \\
\text { eutectic [mass \%] }\end{array}$ \\
\hline Al-3.4 Er & $40 \pm 8$ & 12.5 \\
\hline Al-4.2 Er & $42 \pm 4$ & 16.0 \\
\hline Al-6.1 Er & $53 \pm 9$ & 8.6 \\
\hline
\end{tabular}




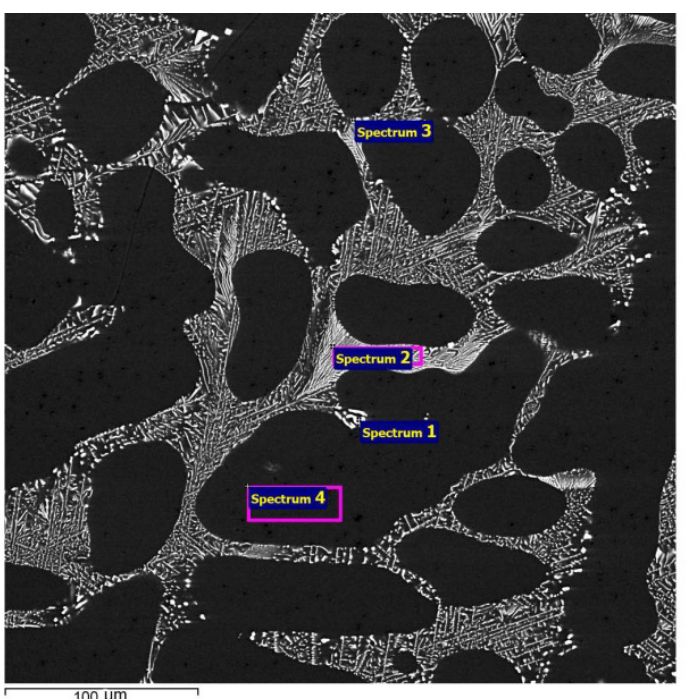

a)

\begin{tabular}{c|cc}
\hline Spectrum & Al [mass \%] & Er [mass \%] \\
Spectrum 1 & 58.05 & 41.95 \\
Spectrum 2 & 85.12 & 14.88 \\
Spectrum 3 & 65.88 & 34.12 \\
Spectrum 4 & 99.73 & 0.27 \\
\hline
\end{tabular}

c)

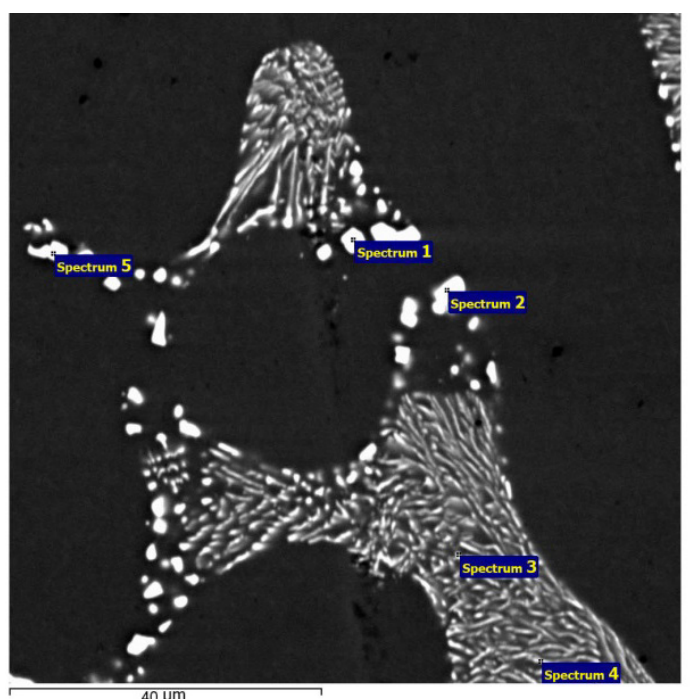

b)

\begin{tabular}{c|cc}
\hline Spectrum & Al [mass \%] & Er [mass \%] \\
Spectrum 1 & 56.63 & 43.37 \\
Spectrum 2 & 45.47 & 54.53 \\
Spectrum 3 & 82.18 & 17.82 \\
Spectrum 4 & 83.50 & 16.50 \\
Spectrum 5 & 51.16 & 48.84 \\
\hline
\end{tabular}

d)

Fig. 3. Microstructure and results of energy dispersive spectrum (EDS) analysis of Al-Er master alloys with 4.2 mass \% Er: a) SEM image; b) SEM image; c) results of EDS analysis of (a); d) results of EDS analysis of (b).

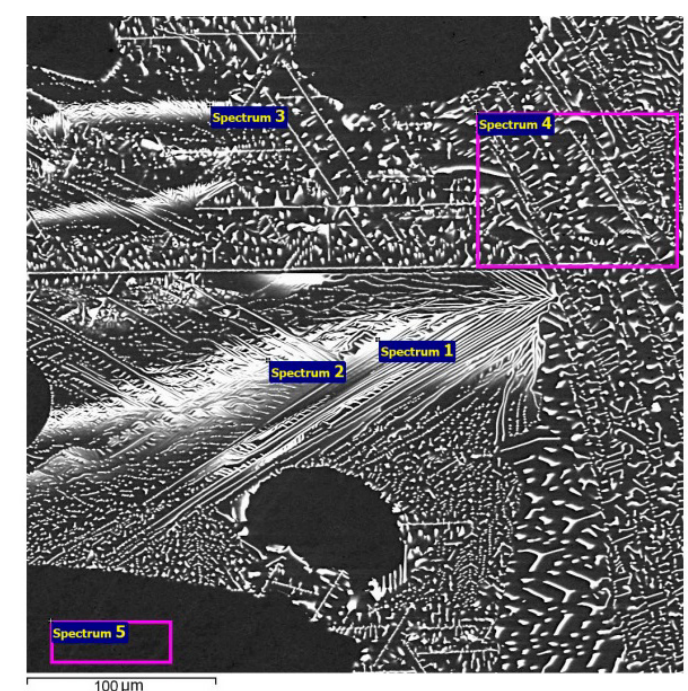

a)

\begin{tabular}{c|cc}
\hline Spectrum & Al [mass \%] & Er [mass \%] \\
Spectrum 1 & 81.72 & 18.28 \\
Spectrum 2 & 82.72 & 17.28 \\
Spectrum 3 & 92.00 & 8.00 \\
Spectrum 4 & 91.04 & 8.96 \\
Spectrum 5 & 99.83 & 0.17 \\
\hline
\end{tabular}

c)

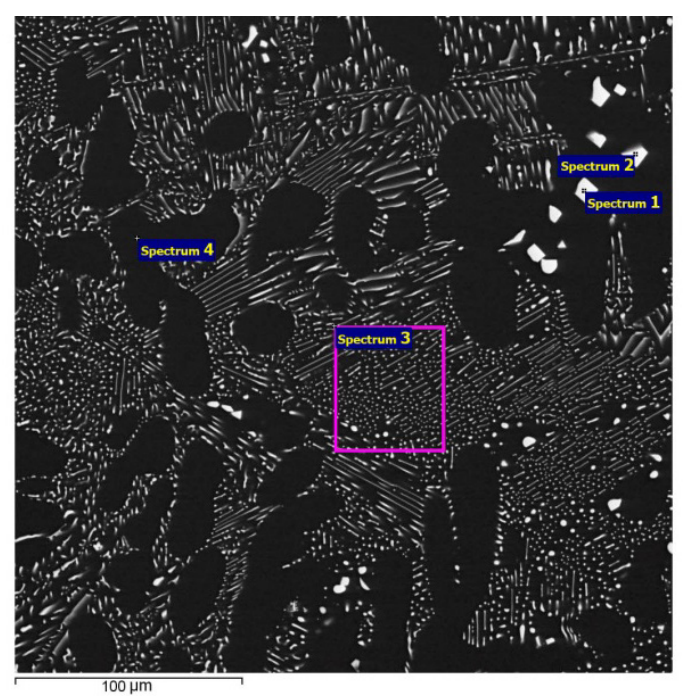

b)

\begin{tabular}{c|cc}
\hline Spectrum & A1 [mass \%] & Er [mass \%] \\
Spectrum 1 & 35.47 & 64.53 \\
Spectrum 2 & 40.78 & 59.22 \\
Spectrum 3 & 90.99 & 9.01 \\
Spectrum 4 & 99.62 & 0.38 \\
\hline
\end{tabular}

d)

Fig. 4. Microstructure and results of energy dispersive spectrum (EDS) analysis of Al-Er master alloys with 6.1 mass \% Er: a) SEM image; b) SEM image; c) results of EDS analysis of (a); d) results of EDS analysis of (b). 
As mass \% content Er increase from 3.4 to 4.2, the mass \% $\mathrm{Er}$ in the eutectic increases from 12.5 to 16.0. With further increase of erbium content up to 6.1 mass $\%$ its content in the eutectic decreases to 8.6 mass \%. Apparently, this is due to the coarsening of intermetallic particles of $\mathrm{Al}_{3} \mathrm{Er}$ by diffusion resistance and reduces the dissolution of erbium in aluminum. It can be seen from Fig. 4 that the microstructure the of Al-6.1\% Er master alloy contains primary crystals of (Al), the eutectic $\left[(\mathrm{Al})+\mathrm{Al}_{3} \mathrm{Er}\right]$, which is crystallized as a coarse needle-shaped and single precipitation of the phase $\mathrm{Al}_{3} \mathrm{Er}$ considerably affecting the dissolutions rate of master alloy.

Overall, the microstructure of the master alloys is fine enough for effective and fast dissolution in the aluminum melt for producing aluminium alloys with low additions of erbium [14].

The XRD analysis of the prepared master alloys has shown the presence of two metallic phases: solid solutions of aluminium (Al) and intermetallic compound $\mathrm{Al}_{3} \mathrm{Er}$ (Fig. 5), which could be in accordance with the phase diagrams.

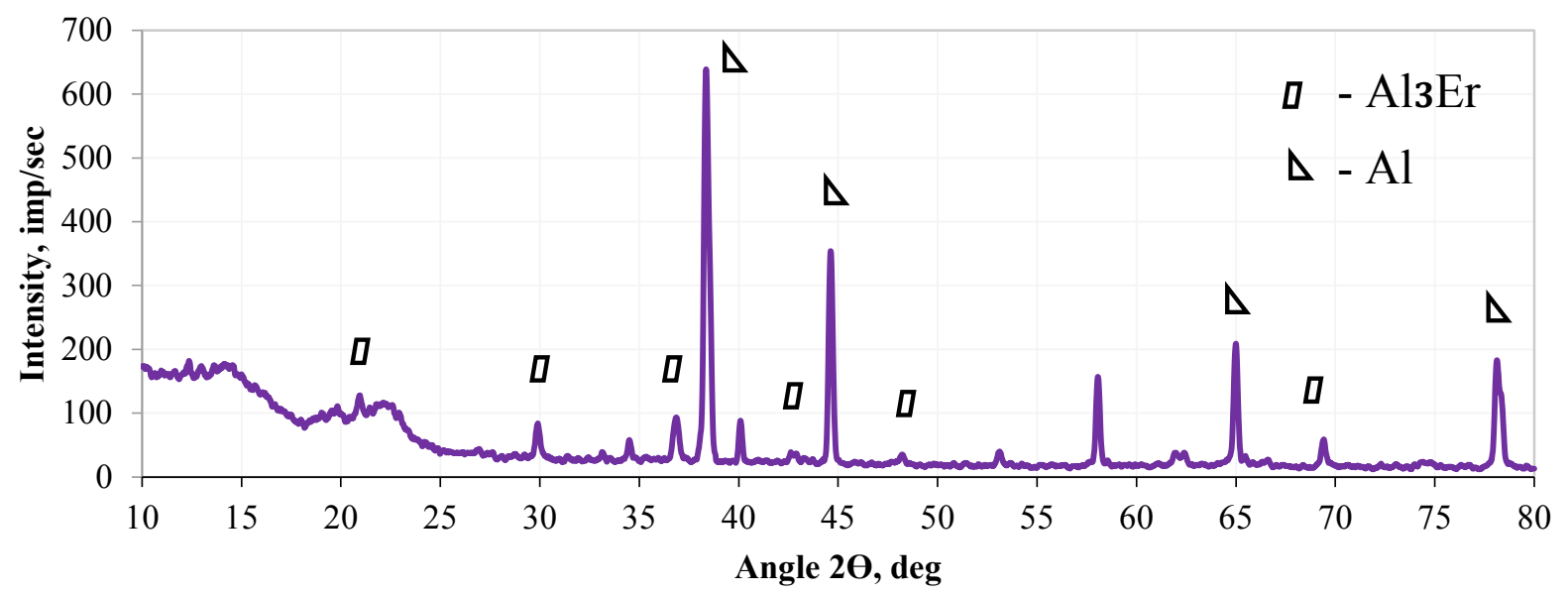

Fig. 5. XRD analysis of the Al-Er master alloys.

The economic results of the process are evident from a comparison of cost of raw materials required for preparation of Al-Er master alloys by aluminothermic reduction of chloride-fluoride melt as well as direct alloying process. The cost of erbium salts as other salt of rare earth is an order of magnitude lower than cost of corresponding metals [22].

\section{Conclusions}

The novel Al-Er master alloys were prepared by the method of metallothermic reduction of chloride-fluoride melt. The interaction between $\mathrm{NaF}$ and $\mathrm{ErF}_{3}$ salts leads to the formation of the complex compound, which produce metal through metallothermic reactions with aluminium melt.

Master alloys prepared by aluminothermic reduction of chloride-fluoride melt used instead of master alloys prepared by direct alloying process to reduce cost of production of alloys and energyefficiency while adding of erbium to aluminum alloys, which is due to the production technology of pure metals from compounds.

The microstructures of the Al-Er master alloy with different contents of the alloying metal have been investigated. The method of metallothermic reduction of chloride-fluoride melt allows to preparation of Al-Er master alloys with content of Er up to 6 mass \% with a fine-grained structure. Erbium content in obtained master alloy depended on the amount of erbium fluoride in original melt.

The master alloys were composed of $\alpha-\mathrm{Al}$ and $\mathrm{Al}_{3} \mathrm{Er}$ phases. With the increase of Er element from 3.4 to 6.1 mass $\%$, the amount of $\mathrm{Al}_{3} \mathrm{Er}$ phase increased and morphology changed from dispersive to coarse needle-shaped.

According to the microstructures analysis of the master alloy it is good enough to be used in the foundry industry. 


\section{References}

[1] M. Colombo, E. Gariboldi, A. Morri, Er addition to Al-Si-Mg-based casting alloy: Effects on microstructure, room and high temperature mechanical properties, Journal of Alloys and Compounds. 708 (2017) 1234-1244.

[2] A. V. Pozdnyakov, D. A. Popov, S. V. Makhov, V.I. Napalkov, Effect of low additions of Y, $\mathrm{Sm}, \mathrm{Gd}, \mathrm{Hf}$ and $\mathrm{Er}$ on the structure and hardness of alloy $\mathrm{Al}-0.2 \% \mathrm{Zr}-0.1 \% \mathrm{Sc}$, Metal Science and Heat Treatment. 58 Nos. 9-10 (2017) 537-542.

[3] N. Su, R. Guan, X. Wang, Y. Wang, W. Jiang, H. Liu, Grain refinement in an Al-Er alloy during accumulative continuous extrusion forming, Journal of Alloys and Compounds. 680 (2016) 283-290.

[4] S.P. Wen, W. Wang, W.H. Zhao, X.L. Wu, K.Y. Gao, H. Huang, Z.R. Nie, Precipitation hardening and recrystallization behavior of Al-Mg-Er-Zr alloys, Journal of Alloys and Compounds. 687 (2016) 143-151.

[5] H. Wu, S.P. Wen, X.L. Wu, K.Y. Gao, H. Huang, W. Wang, Z.R. Nie, A study of precipitation strengthening and recrystallization behavior in dilute $\mathrm{Al}-\mathrm{Er}-\mathrm{Hf}-\mathrm{Zr}$ alloys, Materials Science and Engineering: A. 639 (2015) 307-313

[6] Z.M. Shi, Q. Wang, G. Zhao, R.Y. Zhang Effects of erbium modification on the microstructure and mechanical properties of A356 aluminum alloys, Materials Science and Engineering: A. 626 (2015) 102-107.

[7] N.Q. Vo, D.C. Dunand, D.N. Seidman, Improving aging and creep resistance in a dilute Al-Sc alloy by microalloying with Si, Zr and Er, Acta Materialia. 63 (2014) 73-85.

[8] M Tengfei, C. Ziyong, N. Zuoren, H. Hui, Microstructure of Al-Ti-B-Er refiner and its grain refining performance Journal of rare earths. 31 No. 6 (2013) 622-627.

[9] H. Li, Z. Gao, H. Yin, H. Jiang, X. Su, J. Bin, Effect of Er and Zr additions on precipitation and recrystallization of pure aluminum, Scr. Mater. 68 (2013) 59-62.

[10]C. Booth-Morrison, D. C. Dunand, and D. N. Seidman, Coarsening resistance at $400^{\circ} \mathrm{C}$ of precipitation-strengthened Al - Zr - Sc - Er alloys, Acta Mater. 59 (2011) 7029-7042.

[11]Z.R. Nie, T.N. Jin, G.F. Xu, CN. Patent 1352316 (2002).

[12]R.A. Karnesky, D.C. Dunand, D.N. Seidman, Evolution of nanoscale precipitates in A1 microalloyed with Sc and Er, Acta Materialia. 57 (2009) 4022-4031.

[13]K.E. Knipling D.C. Dunand, D.N. Seidman, Criteria for developing castable, creep-resistant aluminum-based alloys - A review, International Journal of Materials Research. 97(3) (2006) 246265.

[14] S.V. Makhov, V.I Moskvitin, Modern technology of production of aluminum-scandium ligature, Tsvetnye Metally [Non-ferrous metals]. 5 (2010) 95-97 (in Russian).

[15]D.V. Kucenko Recovery of the production intermediates of scandium and its master alloys, Zapiski Gornogo Instituta [Journal of Mining Institute] 155 No1 (2003) 189-192 (in Russian).

[16]C. Xu, X. Liu, F. Ma, Z. Wang, W. Wang, C. Ma, Preparation of Al-Sc master alloy by aluminothermic reaction with special molten salt, 13th International Conference on Aluminum Alloys (ICAA13). (2012) 195-200.

[17]C.V. Makhov, V.I. Moskvitin, D.A. Popov Basis of kinetics and technology of aluminothermic obtaining of $\mathrm{Al}$ - $\mathrm{Zr}$ ligature from $\mathrm{ZrO}_{2}$ in chloride-fluoride salt melts, Tsvetnye Metally [Nonferrous metals]. 11(863) (2014) 69-72 (in Russian). 
[18]V.M. Skachkov, S.P. Yatsenko, Preparation of Sc-, Zr-, Hf-, Y-master alloys based on aluminum by high-temperature exchange reactions in salt melts, Tsvetnye Metally [Non-ferrous metals] 3(2014) 22-26 (in Russian).

[19] V.Yu. Bazhin, Ya.I. Kosov, O.L. Lobacheva, N.V. Dzhevaga, Synthesis of aluminum based scandium-yttrium master alloys, Russian Metallurgy (Metally). 7 (2015) 516-520.

[20]K.A. Gschneidner Jr., F.W. Calderwood, in: T.B. Massalski (Ed.), Binary Alloy Phase diagrams, ASM International, Materials Park, OH, 1990.

[21]N. P. Lyakishev, O. A. Bannykh, L. L. Rokhlin, et al., Phase Diagrams of Binary Metallic Systems: A Handbook, Ed. by N. P. Lyakishev, Mashinostroenie [Mechanical engineering], Moscow, 1996 (in Russian).

[22] A.S. Razinkin, S.P. Yatsenko, B.V. Ovsyannikov, Aluminum-scandium master alloy from lowquality salts for the modification of Al-Mg alloys, Proceedings of the XXIV Russian university. Science and Technology. Moscow: RAS, 3 (2004) 258-266 (in Russian). 